imprisoned for varying periods of time and thus rose to leadership positions within their respective political organizations (of which the student groups at the universities may be considered front organizations). By the end of the 1980s, many of the top-ranking leaders of the popular uprising were individuals who had been student activists at Palestinian universities.

The far-reaching political and social transformations put in motion by the establishment of the first Palestinian authority on Palestinian territory in 1994 have had different implications for the political elite under discussion. While the fortunes of one of its components have risen considerably, the fate of the others is not as immediately obvious.

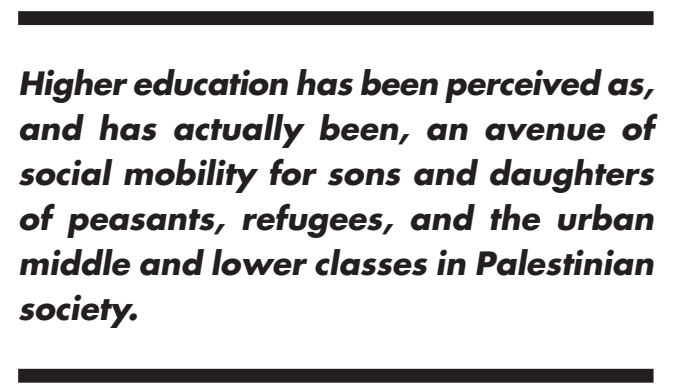

One of the notable features of the Palestinian political system today is its virtual control by the "ruling party," the Fatah movement. For the generation of Fatah student leaders formed in the critical two decades preceding the establishment of the Palestinian Authority, this has meant enhanced influence and social advancement within the ranks of the "state" bureaucracy in formation. Middle-level (and a few high-level and high-profile) posts in Palestinian National Authority institutions are staffed by former student activists of the Fatah movement; their placement in the various security apparatuses is also a striking feature of the current political landscape.

Former leaders of the left student organizations have had a different experience. Faced with the erosion of a sizable portion of their organizations' popular social base, they have pursued two principal avenues for employment and advancement. One has been employment within the expanding public sector, which has been viewed by some observers as a process of co-optation — an effort by the ruling party to neutralize a potential opposition. The other avenue pursued by the more resourceful has been in the growing body of nongovernmental organizations, in which many have found employment opportunities and some leadership positions. It remains to be seen whether these frustrated political careers will find new outlets under the new regime in the form of new parties, or in rejuvenated PLO factions turned opposition parties.

\section{The University Education of Syrian Engineers}

\section{Sari Hanafi}

Sari Hanafi is Senior Researcher at the Centre d'Études et de Documentation Économique, Juridique et Sociale (CEDEJ) in Cairo. Address: CEDEJ, POB 392, Muhammed Farid, Cairo, Egypt. E-mail: <sari@idscl.gov.eg>.

$\mathrm{T}$ his article examines instruction and learning at the university-level in Syria pertaining to the training of civil engineers. The material presented is drawn from data collected in the early 1990s in the course of research for my doctoral dissertation.

\section{French and Syrian Curricula}

The above study compared the training of civil engineers in Syria and in France in two institutional settings-Damascus University and the ENSAIS (Ecole nationale supérieure des arts et industries de Strasbourg). The data reported below relate to Damascus University. It is striking that while curricula are similar in both institutions (with the exception of computer sciences and law and, to a certain extent, the technology of construction), instructional methods differ in two major respects:

- The instruction is based on theoretical training. It is characterized by the virtual absence of vocational or technical education. Appropriate laboratory facilities are either unavailable or underutilized. The university does not maintain ties with either the public or private sector. As a result, students do not have opportunities for practical training.

- Some 85 percent of the lecturers did not assign their students any readings from the professional literature and confined their teaching to the lecture format. Only a minority of them encouraged students to look at issues outside the classroom. This state of affairs is largely a consequence of policies of Arabization and problems related to the inadequate availability of Arabic textbooks.

\section{Politics of Arabization}

University textbooks are often translated into Arabic without any mention of the original source and without any bibliographical references. In fact, producing textbooks for the university is part of the extensive policies of Arabization. Although Syria often boasts at regional and Arabic conferences of its capacity to provide "Arabized" sciences, in engineering the science produced shows mixed results at best and in some cases disastrous outcomes.

Arabization aims to make knowledge accessible to all strata of the population, not just to small a "colonial" elite. 
Nevertheless, in the case of engineering education, Arabization policies produce professionals handicapped by the scarcity of translated books. Further, engineers experience great difficulty in remaining professionally up-to-date. As a result, the Arabization of the sciences, while promoting an agenda of "decolonization," paradoxically reinforces Syria's dependence on the former colonial countries in terms of the engineering sciences and technological knowhow. This problem may go unsolved given the limited financial resources of scientific institutions in Syria and in the Arab world in general.

Arabization policies are not specific to Syria. Yet, the paradigm behind the politics of Arabization in such countries as Syria and Algeria is the substitution of foreign languages (French, English) with Arabic. By contrast, the Tunisian experience is somewhat different as the state imposes Arabic only on certain parts of the curriculum. At the same time, Tunisian students must be proficient in
French, and sometimes even in English, to remain current with foreign sources and textbooks. Syrian university officials perceive such policies to be rather "schizophrenic" in their effects.

\section{Conclusion}

Finally, I am aware that instructional methods in Syrian universities cannot be separated from other general higher education issues-such as, material and financial capabilities, admissions policies, and the imbalance between the huge number of students in a "mass" public system and the small number of faculty. Furthermore, university and faculty libraries are poorly endowed, and there are always difficulties in obtaining foreign publications. This article has attempted to cover problems not directly related to financial capabilities but rather to the underlying educational philosophy in Syrian higher education.

\section{Crossing the Distance: The Open University in the Arab States}

\section{André Elias Mazawi}

André Elias Mazawi is senior lecturer in sociology of education, School of Education, Tel-Aviv University. Address: School of Education, Tel-Aviv University, P.O. Box 39040, Tel-Aviv 69978, Israel. E-mail: <mazawi@post.tau.ac.il>.

$\mathrm{T}$ he concept of an open university and, by implication, that of distance learning remains a widely discussed issue across the Arab states, although open universities are still limited to a very small number of institutions or programs. Institutional, economic, logistic, and political issues are at stake-factors that impede the dissemination of distance higher education in the Arab states. Questions pertaining to inter-Arab relations have also affected the feasibility of such a project. Several attempts to establish open universities have been made since the 1980s. One of these were discussions for the establishment of an Open University for the Gulf States. Other initiatives were undertaken by the Arab League Educational, Cultural and Scientific Organization, as well as by Spain and Morocco in the mid-1980s. More recently, a proposal to establish an Arab Satellite University of Science and Technology was submitted to UNESCO by the U.S.-based National Technological University.

The first full-scale open university to operate remains Al-Quds Open University (QOU), a Palestinian institution opened in Jerusalem in the latter half of 1991. Contacts for its establishment were undertaken between UNESCO and the PLO as early as the mid-1970s, and its first television and radio programs were launched in the mid-1980s. QOU's offices in Amman function as a liaison office coordinating educational matters with the Jerusalem headquarters. The institution extends its services to seven "educational regions"-namely, Jerusalem, Nablus, Ramallah, Bethlehem, Hebron, Gaza, and Jericho. It also operates two study centers, in Tulkarm and Jenin. Based on a credit-hour system, the university grants the equivalent of a B.A. and B.Sc. in a wide array of specializations in the humanities, social sciences, sciences, and educational technology. Quite recently, QOU obtained recognition from the Association of Arab Universities (AArU), becoming the first such higher education institution to join the association.

Calls in favor of establishing an open university for the Arab states continue to be made. It is widely held that an Arab open university would foster cooperation in the field of higher education as countries in the region work to develop their higher educational systems in response to current challenges. Such an institution would also, it is said, provide access to higher education in the region without discrimination based on nationality or gender. Arab officials appear to echo such calls when they stress the need for new alternatives for bringing about the reform and diversification of higher education.

\section{Marginalized Groups}

Women across the Arab states are the largest group directly affected by the dissemination of distance education opportunities-particularly in the Arabian Peninsula and the Magbrib. In Saudi Arabia, for instance, an open university was pointed to as a way to accommodate increased access for women and respect for Islamic customs regarding 